\title{
AS ÁGUAS DO RIO GRANDE E A PREVENÇÃO DE RISCOS: O SIG NA ANÁLISE DE CENÁRIOS PROSPECTIVOS DE USO DO SOLO URBANO EM BOM JARDIM, RJ
}

\author{
THE WATERS OF RIO GRANDE AND THE PREVENTION OF RISKS: GIS FOR THE ANALYSIS OF \\ PROSPECTIVE SCENARIOS OF URBAN LAND USE IN BOM JARDIM, RJ
}

\author{
Ludmila Pacheco Erthal \\ Denise de Alcantara Pereira
}

\section{Resumo}

Este artigo apresenta resultados de pesquisa sobre os riscos da ocupação urbana ao longo da bacia do Rio Grande, em Bom Jardim, RJ. São analisados aspectos relacionados às áreas atingidas por inundações, alagamentos e escorregamento de encostas de modo recorrente e às formas de uso e ocupação do solo em suas margens, em abordagem multiescalar e tipo-morfológica, desde a escala macro - da bacia hidrográfica - até o recorte espacial em foco, adotando como referencial teórico noções de sistemas de espaços livres, unidades morfoterritoriais, morfologia urbana e desenvolvimento sustentável. Metodologicamente, aplicam-se, como diferencial inovativo, ferramentas geocomputacionais para análise e construção de cenários prospectivos sobre o uso e ocupação do solo sob a premissa do ordenamento urbano social e ambientalmente equilibrado. $O$ estudo busca colaborar com a governança local na elaboração de políticas públicas de ordenamento territorial, fornecendo subsídios à elaboração de Plano de Estruturação Urbana para Bom Jardim.

Palavras-Chave: Análise tipo-morfológica. Espaço livre. Uso do solo. Sistema de informação geográfica. Bom Jardim.

\section{ABSTRACT}

This paper presents the results of the research on the risks of urban occupation along the Rio Grande basin, in Bom Jardim, Rio de Janeiro. Aspects related to areas affected by recurrent floods and landslides, and the forms of land use and occupation on its margins are analyzed in a multiscale and typomorphological approach, from the macro - watershed scale - to the spatial cutout in focus, adopting as theoretical reference notions of free space systems, morpho-territorial units, urban morphology and sustainable development. Methodologically, geocomputational tools for the analysis and construction of prospective scenarios on land use and occupation under the premise of socially and environmentally balanced urban planning are applied as an innovative differential. The study seeks to collaborate with local governance in the elaboration of public policies of territorial planning, providing subsidies for the elaboration of the Urban Structuring Plan for Bom Jardim.

Keywords: Typomorphological analysis. Open space. Land use. Geographic information system. Bom Jardim. 


\section{INTRODUÇÃO}

Este artigo apresenta a metodologia e os instrumentos de análise dos espaços livres (Magnoli, 2006) urbanos, aplicados na escala municipal em cidades de menor porte, considerando a importância e a necessidade de pensá-los sob uma ótica própria e específica às suas características. Estudos sobre cidades de pequeno porte tendem a ser menos abrangentes e visíveis do que aqueles relativos às regiões metropolitanas e aos grandes centros, devido às problemáticas existentes nessa escala territorial macro, englobando suas complexidades e dinâmicas. Objetiva-se, assim, analisar - a partir do caso da bacia do Rio Grande, em Bom Jardim, região serrana do Estado do Rio de Janeiro, e da análise tipo-morfológica com uso de sistemas geocomputacionais - como cidades de pequeno porte, como Bom Jardim, estruturam-se e enfrentam as suas problemáticas socioambientais, econômicas e infraestruturais. Objetiva-se ainda a construção de cenários prospectivos de planejamento para aquele recorte urbano afetado pelas torrenciais chuvas que atingiram a região no início da década de 2010.

A análise e construção de cenários prospectivos possibilitam estabelecer o caminho a ser trilhado por uma organização, seja pública ou privada, tendendo a elevar o grau de interações com os ambientes interno e externo. O planejamento por cenários oferece a possibilidade de geração de intenções e orientações para futuros possíveis, prováveis ou desejáveis, com base em decisões feitas no presente (SANTOS, 2013).

O desastre natural de 2011, com enchentes, inundações e escorregamentos, que atingiu toda a região serrana fluminense, representou o ápice de um fenômeno recorrente naquela região, exacerbado pela situação geográfica, ocupação urbana desordenada de encostas e margens de rios, ampliando de forma crítica sua vulnerabilidade socioambiental. Agravando essa situação, o planejamento e gestão pública do município sofrem com a frágil articulação entre governança e participação social e fatores políticos e econômicos, que dificultam a tomada de decisões em momentos de crise. Assim, torna-se urgente repensar a forma e a ocupação urbana a partir do suporte territorial e das características geobiofísicas do lugar, nosso intento neste artigo, de modo a mitigar os reveses de fenômenos naturais e evitar mais perdas patrimoniais e humanas.

As condicionantes físico-espaciais e morfoterritoriais em Bom Jardim, bem como os aspectos ambientais e socioeconômicos, são analisados com base nos conceitos de sistemas de espaços livres de edificações (Tângari et al., 2009) e morfologia urbana (Lynch, 1981; Lamas, 1993). O recorte espacial é delimitado pela Bacia do Rio Paraíba do Sul na escala macro e a microbacia do Rio Grande, na escala local, e o recorte temporal analisa o período a partir dos impactos e transformações ocasionadas pela tragédia de 2011.

A conquista fundamental da instituição da função social da propriedade e do solo urbano, com a promulgação da Constituição Democrática de 1988 (CF88) e do Estatuto da Cidade, propiciou a descentralização do planejamento urbano, outorgando aos municípios maior autonomia (Santin \& Marangono, 2008). O Plano Diretor se afirma, nesse sentido, como instrumento base de ordenamento territorial e o Plano de Estruturação Urbana para aplicação em recortes específicos, bem como a aplicabilidade dos instrumentos urbanísticos em municípios de pequeno porte.

A pesquisa acadêmica realizada sobre o recorte territorial de Bom Jardim, com apoio do grupo de pesquisa GEDUR-UFRRJ', identificou a demanda pela elaboração de um Plano de Estruturação Urbana para a bacia do Rio Grande e a implementação de instrumentos urbanísticos com vistas à recuperação da função social do solo em Bom Jardim, conjugado à elaboração de políticas públicas capazes de fomentar cenários propícios e ambientalmente favoráveis à sua ocupação e uso e à promoção do desenvolvimento sustentável.

O uso de técnicas e métodos para o tratamento de informação espacial em sistemas geocomputacionais configura-se o diferen-

1 Grupo de Pesquisa em Planejamento Urbano e Desenvolvimento Territorial, certificado pelo CNPq, estabelecido em 2012 na Universidade Federal Rural do Rio de Janeiro e liderado por Denise de Alcantara Pereira. Página do grupo disponível em www.gedur-ufrrj.net.br. 
cial inovativo como ferramenta de mapeamento analítico e na construção de cenários prospectivos, com a finalidade de auxiliar na formulação de diretrizes de desenvolvimento urbano. A principal ferramenta de análise diagnóstica e de construção de cenários prospectivos utilizou Sistemas de Informação Geográfica (SIG) na confecção e na análise de mapas temáticos e bases cartográficas, produzidos por meio do cruzamento e espacialização dos dados coletados em levantamentos in loco e imagens de satélite, além de dados cadastrais e estatísticos fornecidos pelo CIDE e IBGE. O aplicativo ARCGIS foi utilizado na elaboração de cenários de ordenamento urbano, evidenciando potencialidades e fragilidades locais. Mapas temáticos foram gerados a partir da aplicação do SIG para espacialização dos aspectos geobiofísicos (topografia, estrutura hídrica), dos aspectos urbanísticos (sistema viário, redes, densidades de ocupação, usos do solo, espaços livres), e ambientais (cobertura vegetal, antropização). Na Matriz de Descobertas, inspirada em Rheingantz et al. (2009), são sintetizados os pontos principais e apresentadas estratégias de planejamento de uso e ocupação do solo; de mobilidade urbana; e de proteção e recuperação ambiental. Tais inovações representam oportunidades para a sua aplicabilidade a partir do entendimento dos alcances e limitações dessas representações na gestão urbana e regional.

Com a intenção de apresentar os resultados da pesquisa, de modo a estabelecer parâmetros e diretrizes de ordenamento territorial do recorte espacial definido pelo núcleo urbano da Bacia do Rio Grande, este artigo se estrutura em quatro partes. A primeira contextualiza o recorte espacial em foco nas diversas escalas, os impactos das chuvas torrenciais de 2011 e apresenta um diagnóstico ambiental do recorte urbano em foco. A segunda parte abarca o arcabouço legal e normativo de caráter ambiental, hídrico e urbanístico, enfatizando a especificidade das problemáticas locais. A terceira parte apresenta os cenários prospectivos de uso e ocupação. A quarta parte apresenta algumas propostas de diretrizes de planejamento, alterações viárias e delimitação de áreas de preservação e proteção.

\section{BaCIA HidRográfica - Bom JaRdim E O Rio Grande}

O município de Bom Jardim está inserido na Bacia do Rio Paraíba do Sul, que abrange parte dos Estados de São Paulo, Rio de Janeiro e Minas Gerais, na VII Região Hidrográfica (VII RH) denominada Rio Dois Rios, no Estado do Rio de Janeiro. A Bacia é formada pela confluência dos Rios Grande e Negro que nascem, respectivamente, em Nova Friburgo e Duas Barras. Os acessos à região ocorrem pelas rodovias RJ 116 e RJ 146, e pela RJ 150, além de 33 estradas intramunicipais, cujo volume diário de tráfego de veículos de passeio representa $75 \%$ do fluxo, seguidos por veículos de carga, motos e transporte público, conforme o Departamento Nacional de Infraestrutura de Transportes ${ }^{2}$. As rodovias atendem ao escoamento da produção agrícola, cimenteira, leiteira e industrial da região serrana para o Rio de Janeiro, tendo ainda acesso ao Arco Metropolitano (BR493), em Itaboraí. Em geral, o sistema viário se adapta à topografia local e segue o traçado dos cursos d'água em suas margens. Pavimentadas nas zonas urbanas, por paralelepípedos ou asfalto, na medida em que se afastam dos núcleos centrais, as vias locais e estradas vicinais não têm calçamento ou drenagem.

Na bacia do Rio Dois Rios, estima-se uma população de 371.255 mil habitantes, sendo 79,9\% em áreas urbanas e 20,1\% em áreas rurais (IBGE, 2010). Apenas um município apresenta população entre 100 a 200 mil, sendo os demais considerados municípios de pequeno porte, como é o caso de Bom Jardim, com população residente de 25.333 habitantes distribuídos de forma concentrada pelo espaço territorial de $385 \mathrm{Km}^{2}$, ou seja, a densidade média é de $65,8 / \mathrm{km}^{2}: 15.266 \mathrm{hab}(60 \%)$ em área urbana e $10.067(40 \%)$ em área rural (IBGE, 2010).

O IDHM em Bom Jardim é 0,660 (PNUD, 2013) sendo o índice de educação o que alcançou maior desenvolvimento, seguidos de longevidade e renda em comparação com índices de educação nacional e estadual com pior desempenho. Apenas $36 \%$ da 2 Cf. a página do DNIT disponivel em servicos.dnit.gov.br/dadospnct/Relatorio/VolumeMedioDiarioMensal 
população com 18 anos ou mais concluiu o ensino fundamental e esse índice se reduz para $20,41 \%$ entre 18 a 20 anos que concluiu o ensino médio. Em termos de renda per capita, em 2010, o município apresentou rendimento médio de $\mathrm{R} \$ 649,62$ (TCU, 2010). Em conformidade com dados apresentados pelo TC-RJ20, é possível estabelecer uma comparação do PIB na Região Serrana a fim de perceber o desempenho do município em estudo. Bom Jardim apresenta o sexto maior PIB per capita da região serrana e indica aumento progressivo até o ano de 2012, evidenciando, entre outros fatores, aumento a bens e serviços. De 2008 a 2013, a receita municipal aumentou em $76 \%$, composta por repasses do Estado e da União totalizando 68,4\%, que somado aos royalties, representa $81 \%$ da receita, sendo que os $19 \%$ restantes são receitas tributárias, de contribuição e patrimonial. As principais despesas municipais se referem à manutenção da máquina pública e serviços prestados à população, incluindo obras de conservação e adaptação de bens móveis. As atividades econômicas de Bom Jardim são agricultura, principalmente café, flores, cereais, legumes e hortaliças, pecuária, confecções de moda íntima, indústrias e serviços. Bom Jardim é o segundo maior produtor de flores de corte.

Observa-se, na década de 2010, um processo de atração de indústrias, principalmente nas proximidades do Distrito de Barra Alegre, promovido por incentivos fiscais oferecidos pela governança local e estadual. A política de desenvolvimento industrial busca melhorar a oferta e qualidade de infraestrutura e urbanização, de características rurais e com diversas carências. Ainda que setores da economia e comércio locais se beneficiem do crescimento industrial, vale lembrar que das 44 indústrias mais poluentes na bacia do Paraíba do Sul. Cinco delas se localizam em Nova Friburgo e despejam seus efluentes tóxicos e não tratados no rio Bengalas, que deságua no Rio Grande, que Bom Jardim margeia, representando cerca de $9 \%$ da área da bacia, sendo um agente contribuidor para o cenário da fragilidade ambiental e de recursos hídricos da região (Figura 1).

Além da poluição, a Agência da Bacia do Paraíba do Sul (AGEVAP, s/d) declara crítica a situação de vulnerabilidade na VII RH, em função das características de relevo e solos que propiciam a erosão, com apenas $22,5 \%$ do território coberto por florestas de Mata Atlântica, sendo o maior índice de cobertura vegetal de toda a bacia. As atividades que impactam diretamente os recursos hídricos são as indústrias têxtil, metalúrgica e cimenteira, mineração, agricultura familiar e turismo ecológico e rural. A agência destaca as ações primordiais para os próximos vinte anos: saneamento básico, eliminando o despejo in natura nos corpos hídricos; o lançamento de efluentes industriais de diversos segmentos; a intensa utilização de agrotóxicos; e, não menos importante, a ocupação desordenada nas margens dos rios (AGEVAP, s/d).

Bom Jardim está inserido na unidade geomorfológica denominada "reverso das colinas e maciços costeiros do Planalto da Serra dos Órgãos", com predominância de morros e montanhas, e ocorrência de relevo suave, subordinados ao domínio montanhoso. Assim, o Rio Grande corre entre encostas íngremes, por cerca de $30 \mathrm{~km}$, às vezes, entre encostas mais suaves, ou paredões e blocos rochosos, com poucos compartimentos alargados em sua calha. A análise hipsométrica (Calderano Filho et al., 2013) indica variação aproximada de elevação entre 400 e 1620 m de altura, e média de $1050 \mathrm{~m}$, havendo o predomínio de morros e escarpas aguçadas. As partes mais baixas, entre 400 e $500 \mathrm{~m}$, circundam o vale do Rio Grande ou o sopé de vertentes. As classes mais altas, com intervalo entre 1.500 e $1600 \mathrm{~m}$ de altura, encontram-se no domínio montanhoso e topos aplainados, a noroeste e sudeste. 0 predomínio é de relevo ondulado, entre 20 a $45 \%$ de inclinação representando $43 \%$ do território municipal, e $69,2 \%$ em áreas com inclinações superiores a $20 \%$. Nesse relevo acidentado, originalmente composto por Mata Atlântica, com domínio de floresta ombrófila densa, o cenário ambiental atual é fragmentado pela antropização, com vegetação original apenas nas áreas de maior altitude. As demais áreas são compostas por atividades agrícolas, mesmo onde havia matas ciliares, tornando essas áreas vulneráveis e susceptíveis à erosão. Nas áreas mais planas, o predomínio do uso do solo é pastagens, cultivos agrícolas, reflorestamentos com eucaliptos e pecuária de corte e leiteira, totalizando $49 \%$ do território. 


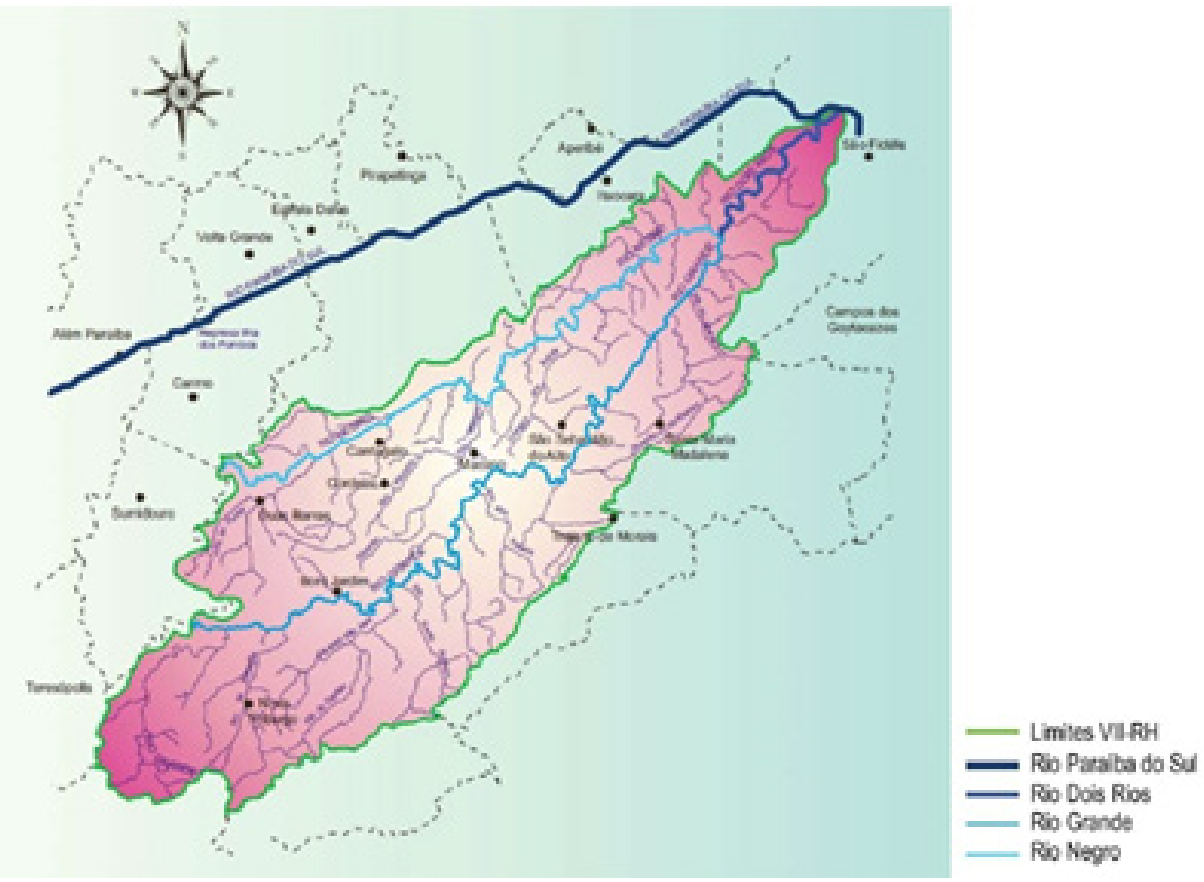

Figura 1 - VII Região Hídrica do Rio Paraíba do Sul. Edição sobre base cartográfica extraída do relatório da $\operatorname{AgEVAP}(\mathrm{s} / \mathrm{d})$

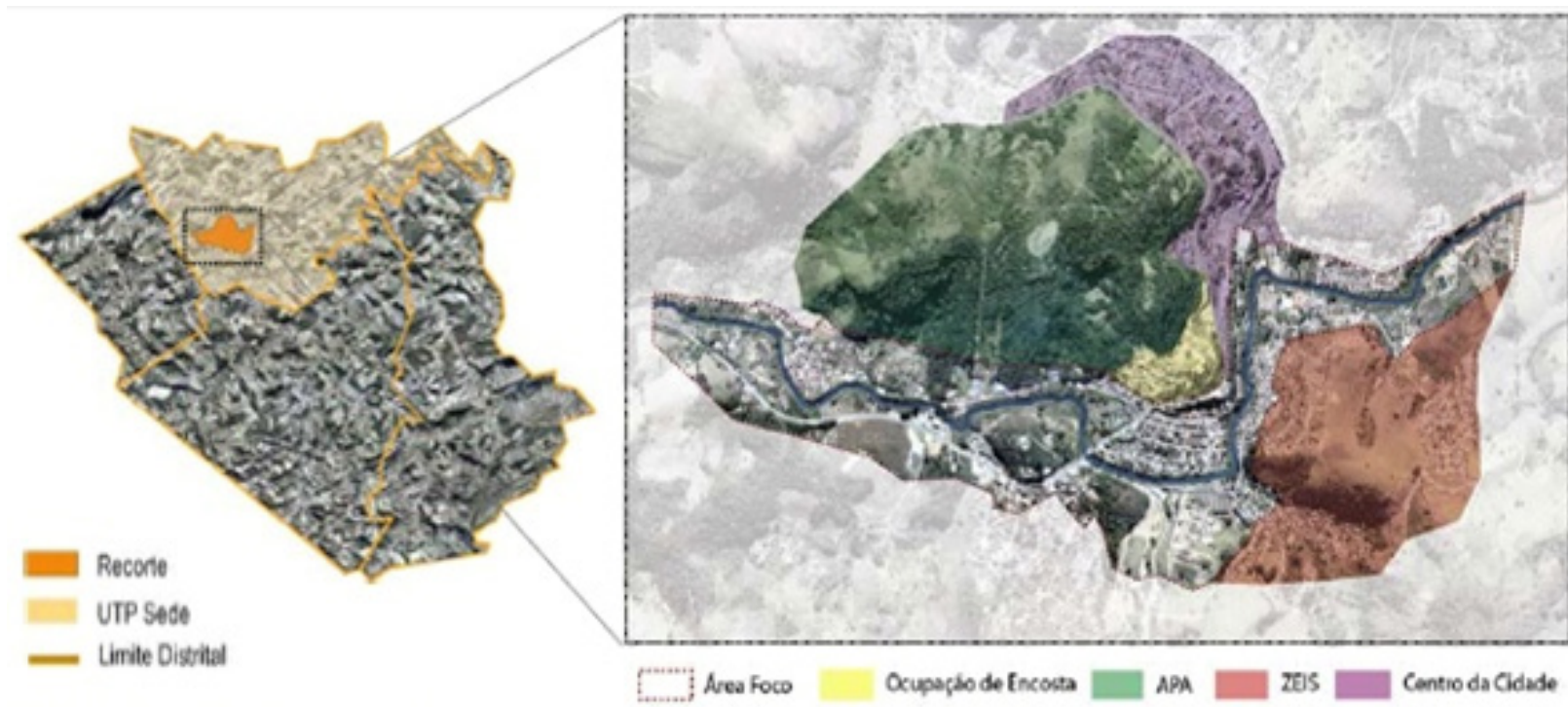

Figura 2 - Mapa do município, recorte da microbacia e delimitação da área foco.

Fonte: Edição própria sobre imagem de satélite. Edição dos autores em ArcGis, 2017. 
Situado na Serra do Mar, apresenta intenso regime pluviométrico característico do relevo e do tipo climático mesotérmico úmido, com temperaturas elevadas bem distribuídas ao longo do ano e pouco ou nenhum déficit hídrico. O verão é brando, com temperatura média anual de $17,8^{\circ} \mathrm{C}$ e mínima de $13^{\circ} \mathrm{C}$ no inverno. A média anual observada no período de 1996 a 2007 apresentou médias entre $1.327 \mathrm{~mm}$ a $1.585 \mathrm{~mm}$ (Calderano et al., 2013). Todo o município é susceptível a alagamentos, enxurradas e corridas de massa, por conta do relevo acidentado, da variada textura do solo, do relevo montanhoso e do alto regime pluviométrico. A pressão sobre o uso da terra, a reduzida área vegetada e a falta de planejamento e de técnicas apropriadas de ocupação, intensificam a erosão e a perda de solo fértil, contribuindo com a degradação dos recursos naturais. Em função das susceptibilidades da região, Bom Jardim apresenta vulnerabilidade alta e muito alta à erosão do solo e estudos geoambientais recentes confirmam a intensificação das vulnerabilidades ampliando a fragilidade dos recursos hídricos e do sistema ambiental (AGEVAP, sd).

Em janeiro de 2011, um evento catastrófico se abateu sobre a região serrana do Estado, assolando os municípios de Areal, Bom Jardim, Nova Friburgo, Petrópolis, Sumidouro, São José do Rio Preto e Teresópolis, que decretaram estado de calamidade pública. Considerado o maior desastre climático do Brasil com maior número de vítimas e o oitavo maior deslizamento de terra do mundo nos últimos 100 anos $^{3}$, os números oficiais indicam mais de 900 mortos, 50 mil desabrigados e 300 mil pessoas diretamente afetadas. Cerca de $42 \%$ da população da região serrana foi diretamente atingida, envolvendo uma verdadeira força tarefa com os três níveis de poder em ações emergenciais e início de reestruturação. $O$ fenômeno afetou distintamente cada uma das cidades, devido aos fatores geológicos e morfológicos e pela intensidade e direção de deslocamento da precipitação, mas tanto áreas urbanas, quanto áreas rurais sofreram com deslizamentos e enxurradas. Nas partes mais altas, a baixa infiltração da água causou o escorregamento superficial de vegetação da formação rochosa, gerando avalanches que devastaram e soterraram o que estava em seu caminho, e bairros inteiros sucumbiram à força da 3 Classificação da ONU natureza. Nas partes mais baixas e planas, as enxurradas se diferenciaram pelo maior ou menor grau de sedimentos depositados ou arrastados, estando muitos casos de deslizamentos associados a algum tipo de ocupação antrópica (MMA, 2010). A Bacia do Rio Grande concentrou o maior número de óbitos, devido aos mais de três mil escorregamentos e inundações de Nova Friburgo, porém, no trecho de Bom Jardim, verificou-se majoritariamente a ocorrência de enxurradas e enchentes. Ainda assim, o prejuízo patrimonial e material foi grande, com muitas famílias desalojadas e com perda total de bens ${ }^{4}$. Estima-se que $49 \%$ população tenha sido afetada, incluindo 632 desabrigados, 1.186 desalojados, 423 feridos e uma morte. Três dos quatro distritos de Bom Jardim apresentaram pontos de alagamentos e enxurradas, exceto Barra Alegre, que não foi atingido de forma direta.

O setor habitacional foi o segundo maior impactado, em relação ao total de domicílios destruídos $(5,38 \%)$ ou que sofreram algum tipo de dano $(12,18 \%)^{5}$, além das práticas de valorização da terra, ligadas ou não às áreas de risco e à supervalorização dos preços dos imóveis pós-desastre. Adotou-se como medida emergencial o pagamento de aluguel social às famílias que perderam as suas casas. Entretanto, muitos retornaram às antigas moradias, causando uma maior burocratização e lentidão nos processos relativos às negociações; dissidências entre a população e órgãos responsáveis; falta de conscientização da população exposta aos riscos; supervalorização dos preços dos aluguéis; demora na construção e entrega das habitações de interesse social; e carência de projetos de planejamento relativos às habitações. Dos três empreendimentos previstos para abrigar 240 unidades habitacionais, apenas $28 \mathrm{UHs}$ de $39 \mathrm{~m}^{2}$ haviam sido entregues no distrito de Banquete, até 2017.

Quanto à infraestrutura de transportes, os maiores impactos referem-se à destruição total ou parcial das vias, o desmoronamento de pontes, ocasionando um cenário caótico e transtornos ao município. Na RJ-116, principal via de acesso à Bom Jardim,

4 Apesar de não confirmado oficialmente, a prefeitura estimou em 75 milhões, em valores da época, o custo da reconstrução.

5 Secretaria Nacional de Defesa Civil e Defesa Civil do Rio de Janeiro - Relatório de Perdas e Danos elaborado pelo Banco Mundial. 
barreiras e desmoronamentos das pistas dificultaram as ligações intra e interurbana. Seu funcionamento foi interrompido por um ano devido à queda da ponte sobre o Rio Grande, afetando outros pontos da cidade com desvios e conexões intrabairros. Além da sede, Banquete e São José também tiveram suas pontes arrastadas pela força da água, isolando algumas comunidades rurais dos distritos centrais e restringindo a distribuição da produção. Foram computados danos a uma passagem de pedestres e dez pontes destruídas; $400 \mathrm{~km}$ de estradas danificadas e $120 \mathrm{~km}$ destruídos; e em relação à pavimentação das vias urbanas, 76 mil metros quadrados danificados e $30 \mathrm{mil} \mathrm{m2}$ destruídos (Banco Mundial, 2012). Ademais, houve danos na infraestrutura urbana, com interrupções no abastecimento de água, energia, telefonia e internet durante vários dias, reforçando a condição de isolamento. Além dos diversos transtornos materiais gerados, houve grande prejuízo econômico, com estoques de comércios perdidos na lama, produção agrícola arrasada, produtos perecíveis não entregues, e até mesmo empresas que não foram atingidas diretamente, tiveram que ser paralisadas por falta de matéria-prima ou de funcionários que não podiam se deslocar. (Fig. 3)

Em meio ao cenário de destruição projetado sobre a cidade, indaga-se que ações seriam capazes de evitar ou mitigar a sequência de acontecimentos previsíveis, dado que, vivemos em um período de mudanças climáticas, com eventos que se repetem e se intensificam, afetando ora um bairro, ora regiões inteiras. As áreas antropizadas sentem mais este efeito: áreas que deveriam estar protegidas, ocupações precárias e irregulares; desrespeito às legislações ambiental e urbanística; omissões, ausências ou falhas dos órgãos e políticas públicas; e falta de planejamento. Os interesses pessoais ou coorporativos em detrimento do coletivo corroboram para ocorrência desses eventos desastrosos cada vez mais frequentes, colaborando para desqualificação do

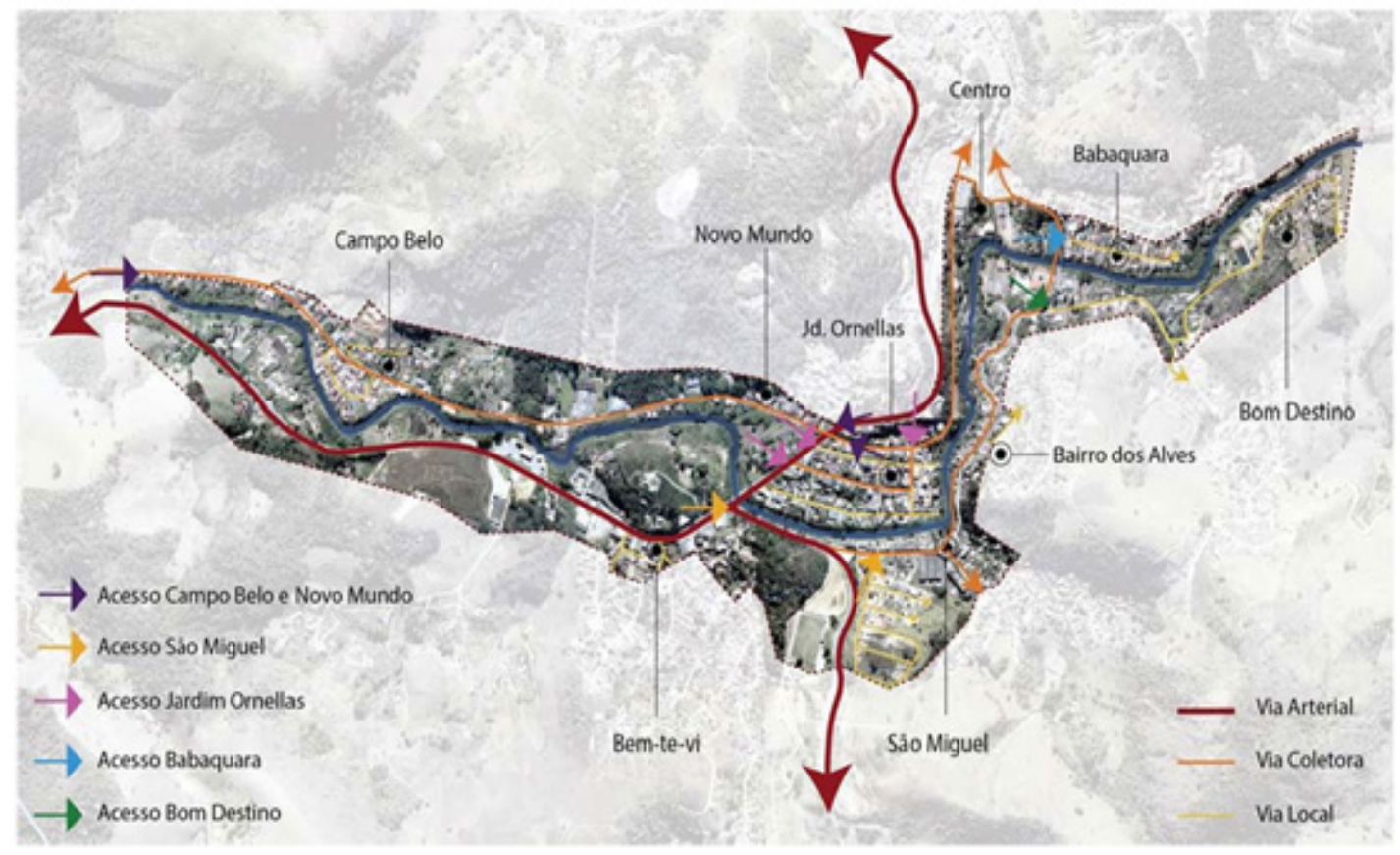

Figura 3 - Delimitação da área foco com maior aproximação do núcleo urbano e os principais eixos viários mais afetados pela tragédia de 2011.

Fonte: Edição própria sobre imagem de satélite em ArcGis, 2017. 
meio. Seriam o poder público e as governanças locais os principais responsáveis? Ou a pressão da expansão urbana sobre áreas de risco? Ou a pressão dos setores empresariais? Ou ainda as condições desiguais da distribuição de renda que fomentam segregação socioespacial e falta de engajamento por partes da população?

A conscientização se faz necessária, não de um agente ou setor, mas de todos os que almejam uma sociedade mais justa, com cidades mais saudáveis e seguras. A população deve estar articulada com o poder público para que as decisões sejam de fato democratizadas, consideradas as demandas e respeitadas as condicionantes geobiofísicas e ambientais.

No sentido de buscar respostas para as perguntas acima, a análise tipo-morfológica, quando realizada em diferentes escalas, proporciona diferentes meios de atuação e intervenção. Assim, na elaboração do diagnóstico na microescala, estabelecendo relações entre a área de estudo e recortes específicos, são identificados aspectos da mobilidade e sistema viário, ocupação territorial, uso do solo topografia e vulnerabilidades ambientais, abrangendo levantamentos in loco e análise de imagens de satélite. Tais leituras espaciais auxiliaram na aplicação dos conceitos de sistemas de espaços livres e classificação do recorte em Unidades de Paisagem (UP), conforme método apresentado por Sampaio et al. (2009), objetivando a produção de mapas como ferramenta de compreensão das dinâmicas sócioespaciais. As bases cartográficas desenvolvidas com o aplicativo ArcGis configuram um avanço inovativo na análise socioespacial de municípios de pequeno porte. A classificação das UPs ocorre em duas escalas: a partir da delimitação da microbacia, de parâmetros de drenagem e relevo, tipo de ocupação, cobertura vegetal e usos e atividades. Na escala municipal foram identificadas quatro UPs: a mancha urbana mais adensada (UP1); duas com predominância de cobertura vegetal, uma mais densa e outra rarefeita; e finalmente áreas de produção de café. Na escala local, identificaramse sete subunidades (Fig. 4):

- UP1.1 - Centro; dinâmica própria, mais denso, com diversos usos.
- UP1.2 - Menos adensado com pouca oferta de comércio e serviços; áreas de risco a alagamentos e enxurradas.

- UP1.3 - Tecido não totalmente consolidado, ocupa desde o sopé até o topo da montanha, com boa oferta de áreas livres.

- UP1.4 - Tecido em consolidação, áreas mais densas e outras mais dispersas, vulneráveis a inundações, enxurradas e deslizamentos.

- UP1.5 - Zonas de expansão, baixa densidade construtiva, ocupação de encostas, sem oferta de comércio e serviços, infraestrutura básica e transporte público para essas zonas.

- UP1.6 - Áreas centrais de uso especial: cemitério, fazenda histórica, o Galpão cultural, usina histórica, parque urbano e Clube; os três últimos sujeitos a alagamentos e enxurradas.

- UP1.7 - ZEIS - As zonas de assentamentos precários, alta vulnerabilidade social, ocupação desordenada e pouca infraestrutura; vulnerabilidade a escorregamentos.

O mapa de Uso e Ocupação do Solo (Fig. 5) evidencia áreas mais ocupadas e a disponibilidade de espaços livres existentes. Ao sobrepô-lo com o mapa de suscetibilidades e topografia, pode-se identificar as áreas passíveis de adensamento e as que devem ter ocupação restringida. Em São Miguel ocorre comércio local. As outras áreas são essencialmente residenciais, com carência de equipamentos de lazer e recreativos. Nas faixas marinais da RJ116 , surgem comércios e serviços que atendem a cidade como um todo.

O Mapa topográfico (Fig. 6) revela uma amplitude altimétrica de aproximadamente $320 \mathrm{~m}$, em que as partes mais baixas, junto às margens do Rio Grande, encontram-se a partir da cota $565 \mathrm{~m}$ em relação ao nível do mar e altitude de até $870 \mathrm{~m}$. São delimitadas as áreas passíveis de inundação e a sobreposição com a topografia e a área foco. Percebe-se que grande parte do vale do Rio Grande está exposta ao risco de inundação.

Diversos cortes esquemáticos foram realizados a fim de perceber o comportamento do relevo, a ocupação e a transformação da 

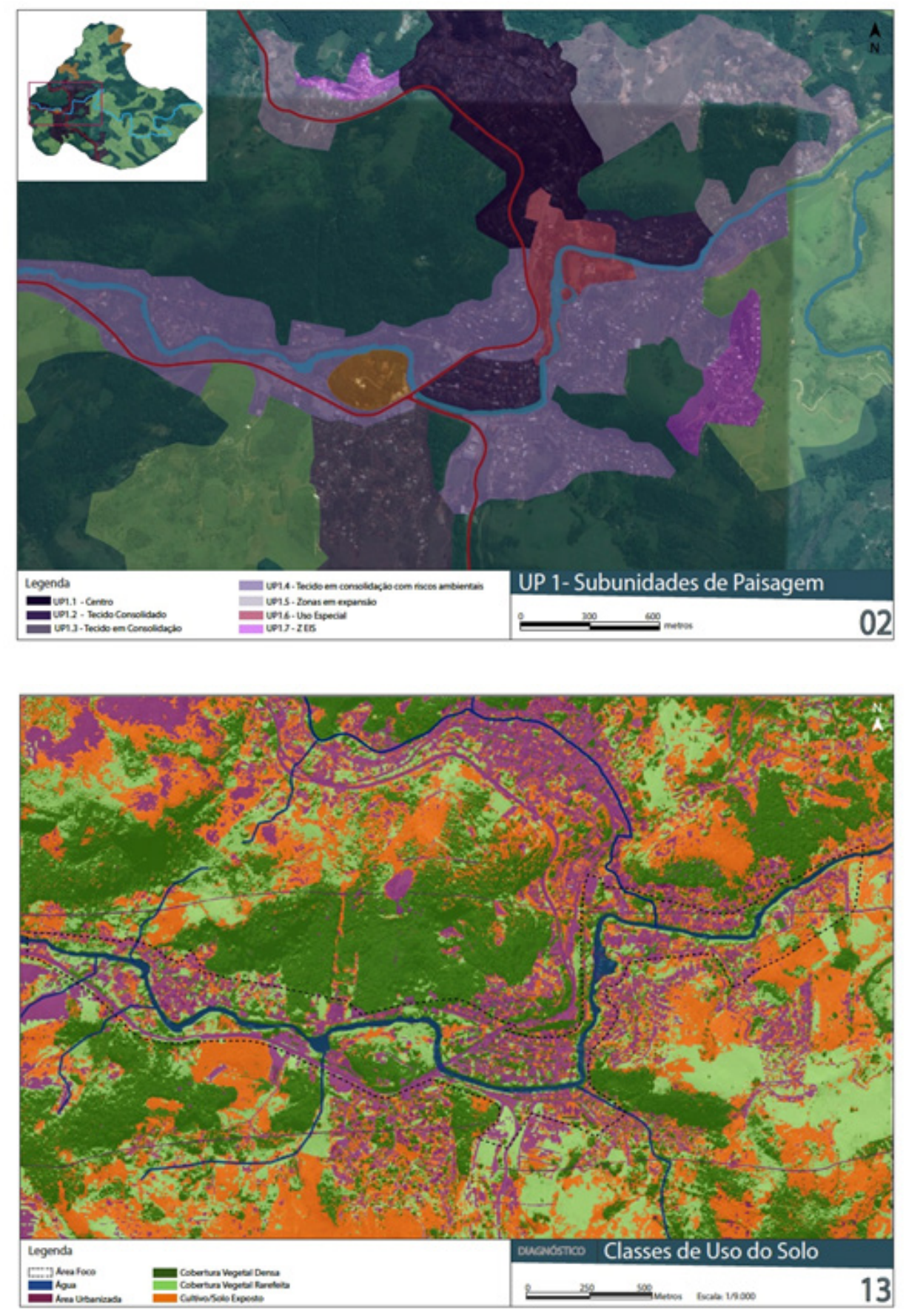

Figura 4 - Mapa da UP1 com indicação das sete subunidades de paisagem.

Fonte: Edição própria em ArcGis, 2017
Figura 5 - Mapa de Uso e Ocupação do Solo. Fonte: Edição própria em ArcGis 


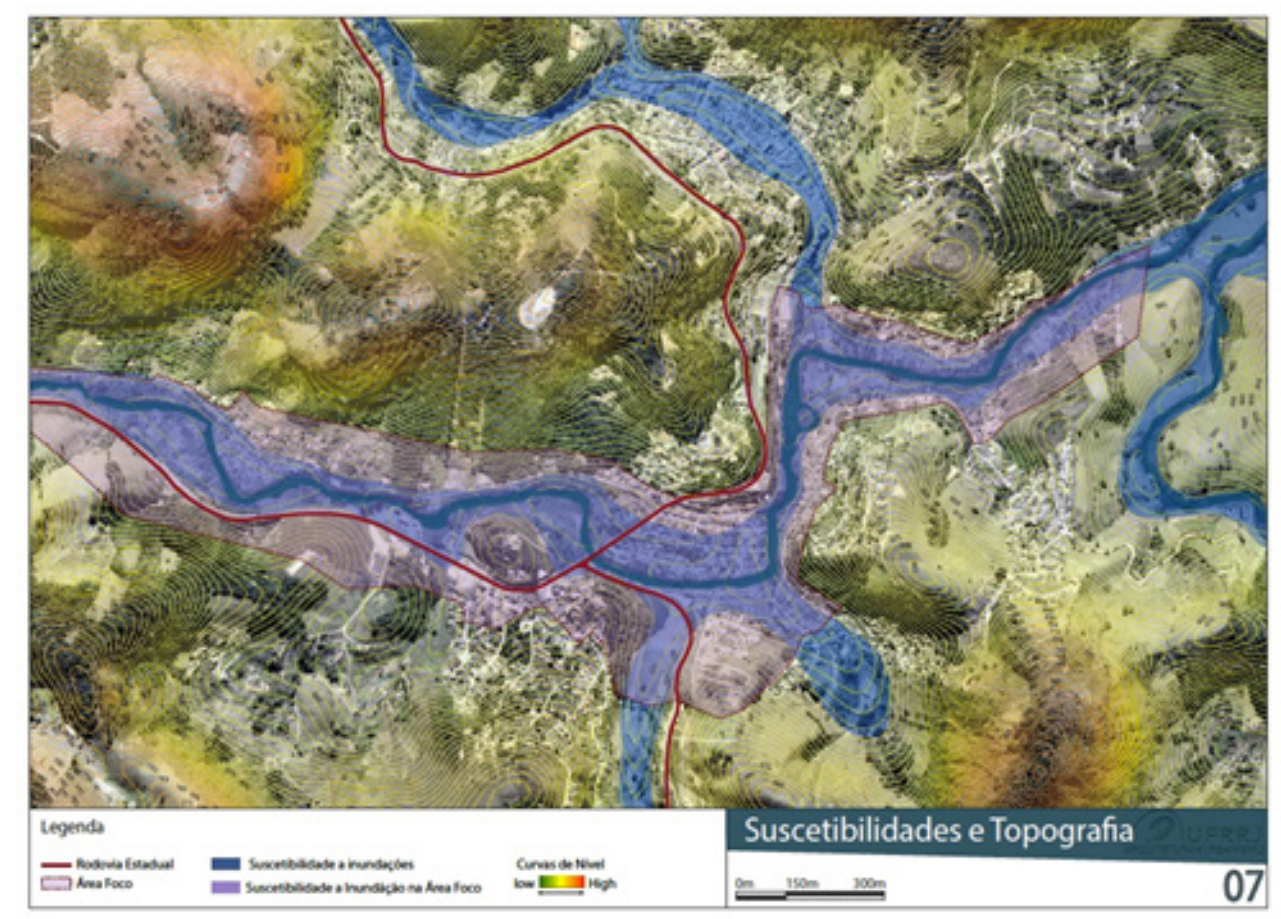

Figura 6 - Mapa de Topografia e Susceptibilidades. Fonte: Edição própria em ArcGis

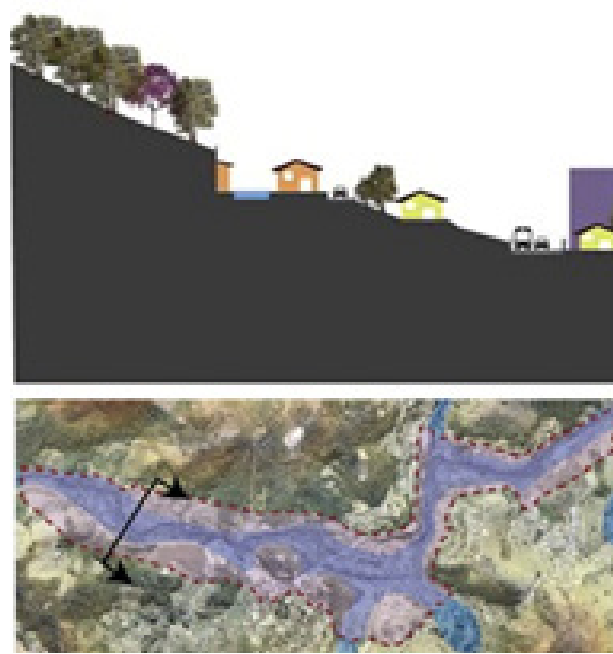

Figura 7 - Corte 1 - Campo Belo.

Fonte: Edição própria em ArcGis e AutoCad

\section{Corte 1 - Campo Belo}



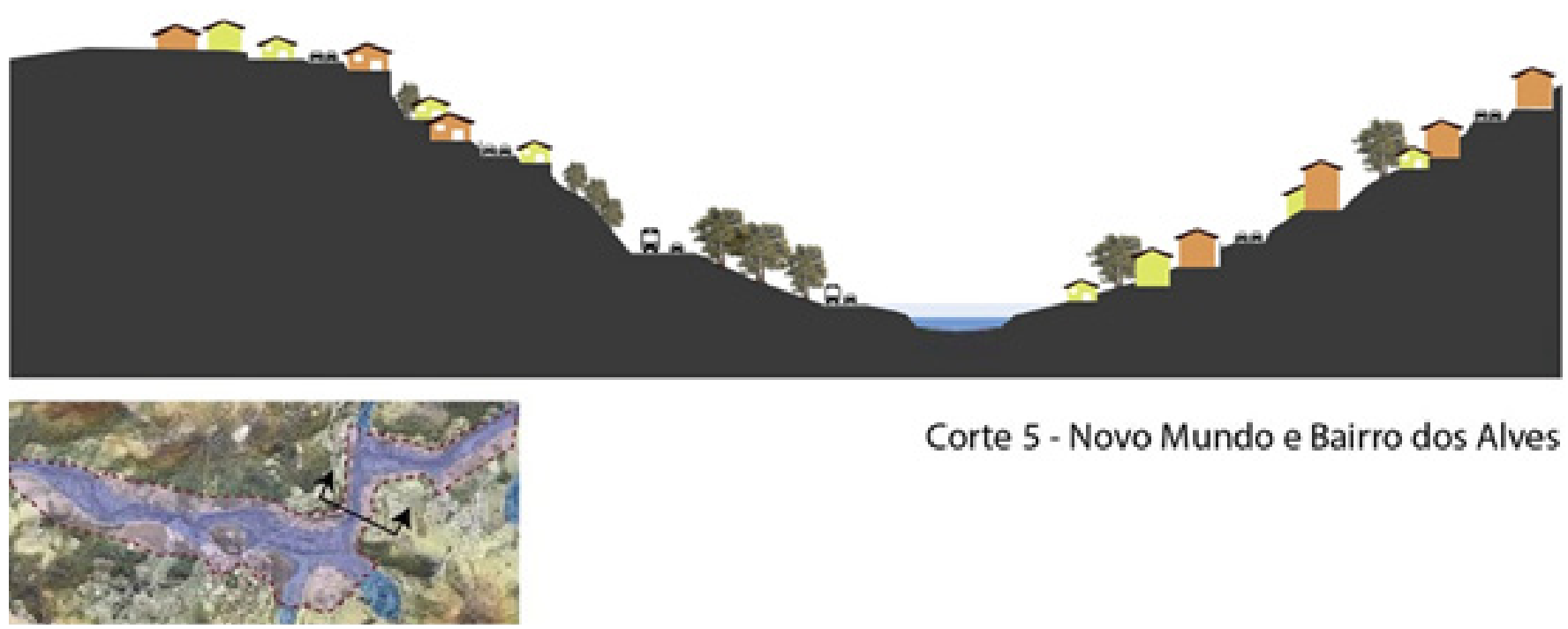

Corte 5 - Novo Mundo e Bairro dos Alves

Figura 8 - Corte 5 - Novo Mundo e Bairro dos Alves.

Fonte: Edição própria em ArcGis e AutoCad

paisagem ao longo do percurso junto ao Rio Grande, bem como, a relação do ambiente construído com o relevo. Apresentamos os Cortes 1 e 5, a título de exemplo, que ilustram como diversos trechos do Rio Grande estão sujeitos a cheias, alagamentos, enxurradas e escorregamento de encostas, enquanto que demonstram com clareza o risco presente pela ocupação irregular, ausência de contenções, contaminação do solo pela presença de lixão desativado em cota acima da área urbanizada, entre outras susceptibilidades presentes em suas margens. $\mathrm{Na}$ análise, os cortes são acompanhadas com mapas de cada área, respectivamente. (Figs 7 e 8).

Ao final do diagnóstico foi elaborada uma matriz com os principais conflitos e as potencialidades, inspirada no instrumento Matriz de Descobertas (Rheingantz et al. 2009). (Fig. 9)

\section{Aporte Legislativo}

O Plano Diretor (PD), conforme preconizado polo Estatuto da Cidade, é o instrumento básico de planejamento social, econô- mico e territorial para que o município oriente ações, investimentos e políticas públicas, adeque seu orçamento e promova a integração estimulando a participação da população nas decisões e gestão dos espaços urbanos incorporando as ações da cidade como um todo, prevendo a complementariedade dessas ações com as áreas rurais (Brasil, 2004). Apesar do inquestionável avanço proporcionado pela difusão dos PDs, a prática nos mostra que somente a constituição de leis, mesmo as que privilegiam interesses coletivos em detrimento dos privados, não é suficiente para reduzir as desigualdades em nossas cidades. Maricato e Santos (2007) alertam sobre a crise urbana, afirmando que apesar da questão urbana estar em evidência, essa pauta não é prioridade na agenda política brasileira, inferindo que o poder de como se dá a produção e a apropriação do espaço físico é constantemente ignorado. Apenas aqueles que trabalham para o capital imobiliário enxergam o espaço urbano como ativo financeiro e econômico, em que o valor da terra varia em função das leis e investimentos influenciados por lobistas, que atuam sobre o orçamento público e direcionam os investimentos públicos. Villaça (1998) já afirmava que o planejamento ur- 


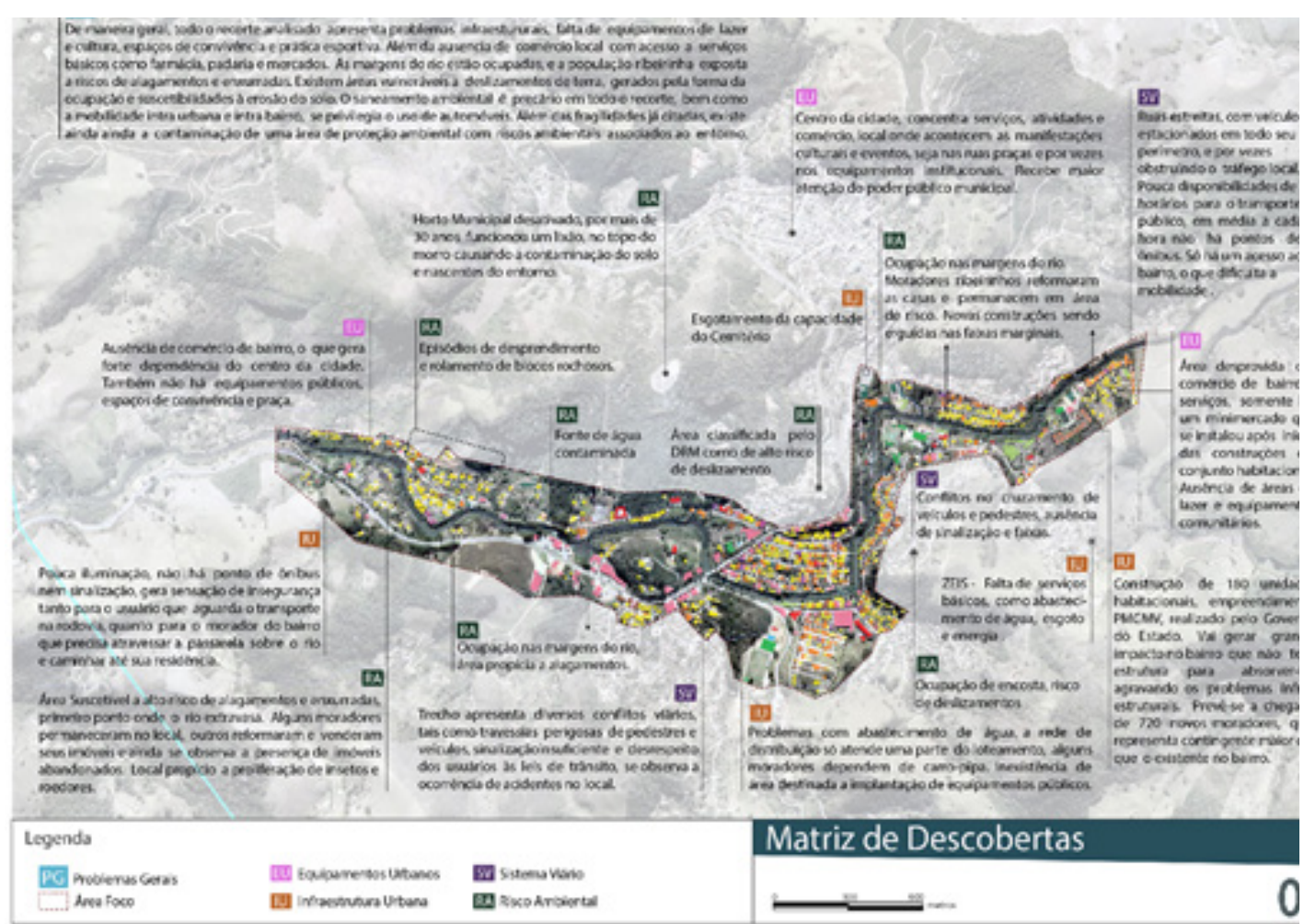

Figura 9 - Matriz de Descobertas com os principais conflitos e potencialidades identificados na análise da microbacia do Rio Grande, em Bom Jardim.

Edição própria com base em Rheingantz et al. (2009) bano desenvolvido pelos PDs tem existido somente na teoria, estando a cargo do zoneamento e do controle dos loteamentos em sua existência real. Isso se refere à utilização dos PDs antes da promulgação do Estatuto das Cidades, mas que, quando ampliada sua análise, auxilia-nos a refletir sobre as reais situações de aplicabilidade dos planos urbanísticos ou de planejamento que acabam por gerar um cenário de descrença em relação aos mesmos. Torna-se necessário ampliar a discussão quando pensamos na realidade das cidades brasileiras, que inclui avaliar o contexto em que se desenvolvem, e a real conjuntura dos municípios para cumprir e executar os instrumentos urbanísticos de forma eficiente.

A partir da observância da legislação municipal e dos instrumentos de planejamento legais, determinados pelo PD, podem ser definidos recortes específicos de ordenamento territorial a partir de um Plano de Estruturação Urbana (PEU), que irá estabelecer um conjunto de diretrizes e parâmetros que visem a organização espacial de uma determinada área do território municipal, abrangendo um ou vários bairros. O objetivo principal de um PEU é (re) qualificar o ambiente urbano e auxiliar no processo de desenvolvimento e implementação de políticas públicas e da gestão da governança local. Dentre as etapas para seu desenvolvimento e implementação, primeiramente, define-se a área de estudo objeto da intervenção; posteriormente, estuda-se, por meio de dados estatísticos e levantamentos em campo, informações relevantes para a realização de um diagnóstico que incidirá numa proposta inicial. São investigadas as características do suporte geobiofísico, aspectos socioeconômicos, culturais e ambientais da região, a fim de direcionar ações e investimentos. A identificação dos anseios da população e a ponderação dos impactos causados na localidade e no cotidiano das pessoas afetadas devem ser contempladas a partir da elaboração da proposta e agendadas audi- 
ências públicas para apresentação e debate do Plano e revisões, para votação e aprovação pelo Poder Legislativo na forma de Lei Complementar.

Alguns parâmetros básicos incluídos na proposição dos PEUs, como reguladores do ordenamento territorial e uso e ocupação do solo, dizem respeito: às dimensões mínimas e máximas de lote, aos afastamentos mínimos, às taxa de ocupação, à taxa de permeabilidade, à área total edificável, ao Índice de Aproveitamento do Terreno ou Coeficiente de Aproveitamento e ao gabarito ou às alturas máximas permitidas. Normalmente definidos genericamente pelo PD ou legislação específica, tais parâmetros podem se adequar a situações específicas e devem ser utilizados ajustados à realidade local, às limitações e à estrutura para realizá-lo. Nesse sentido, neste estudo considera-se a elaboração de um PEU que atente às questões ambientais e à exposição da população a riscos, gerados por eventos climáticos, vulnerabilidades do suporte físico e sociais ou decorrentes da forma de ocupação do território.

\section{Cenários Prospectivos - Riscos e POTENCIALIDADES}

Considerando a legislação, a análise de comportamento do relevo e da hidrografia, e o histórico de desastres naturais e ambientais ocorridos, são sugeridos três tipos de Áreas de Preservação Permanente (APPs):

- APP1 - áreas adjacentes às margens dos rios cujos usos estão estabelecidos no código Florestal e na Lei das Águas. São permitidas: edificações de acordo com critérios determinados pelas diretrizes de uso e ocupação do solo; implantação de vias de circulação, equipamentos de lazer e esporte e infraestrutura urbana; de interesse público, para fins de saneamento ambiental e drenagem urbana. O parcelamento não é permitido.

- APP2 - declividade maior ou igual a $45 \%$; proibidos assentamentos humanos; permitida abertura de vias e implantação de equipamentos de utilidade pública, conforme APP1.
- APP3 - declividade ente 30 e $45 \%$; lei 6.766 , sendo permitidas as ocupações com restrições, e sugestões de ocupações em áreas de relevo inclinado.

Complementarmente, desenvolve-se uma análise por meio de método de classificação de imagem assistida, com auxílio do software Arcgis para classificar os usos do solo no recorte proposto relativo à categorização de usos do solo. Os dados obtidos são cruzados com a delimitação das APPs, evidenciando conflitos entre o uso do solo e as áreas de preservação. O resultado está exposto no Mapa de Conflitos APP x Uso do Solo, que identifica os conflitos nas margens do Rio Grande e nas áreas de maior declividade, demonstrando a predominância de solo exposto ou áreas de cultivo, que agravam a erosão do solo. (Fig. 10)

Assim, verifica-se que na APP1, 554 edificações estão construídas em APP, demandando-se uma análise criteriosa para definir a permanência ou demolição dessas edificações. Na APP2, são identificadas áreas que devem ser recuperadas e/ou reflorestadas, a fim de reestabelecer suas funções ecológicas. Na APP3, identifica-se áreas que devem ser revitalizadas por meio de plantio em zonas de solo exposto, vistorias das edificações existentes e verificação de risco e permissão de parcelamentos do solo somente após liberação por corpo técnico capacitado, mediante apresentação da carta de aptidão geotécnica.

\section{INFRAESTRUTURA VERDE NA ESCALA LOCAL}

A infraestrutura urbana definida como um sistema de equipamentos e serviços necessário ao desenvolvimento das funções urbanas é abordada a partir do conceito de infraestrutura verde aplicada à escala local. As análises apontam para a falta de tratamento de efluentes domésticos e industriais, com intuito de mitigar os efeitos das enchentes. Indica-se a aplicação de medidas estruturais extensivas, tais, como:

Bacia de retenção, para reduzir o caudal do rio e receber o excedente da drenagem pluvial, armazenando a água, juntamen- 


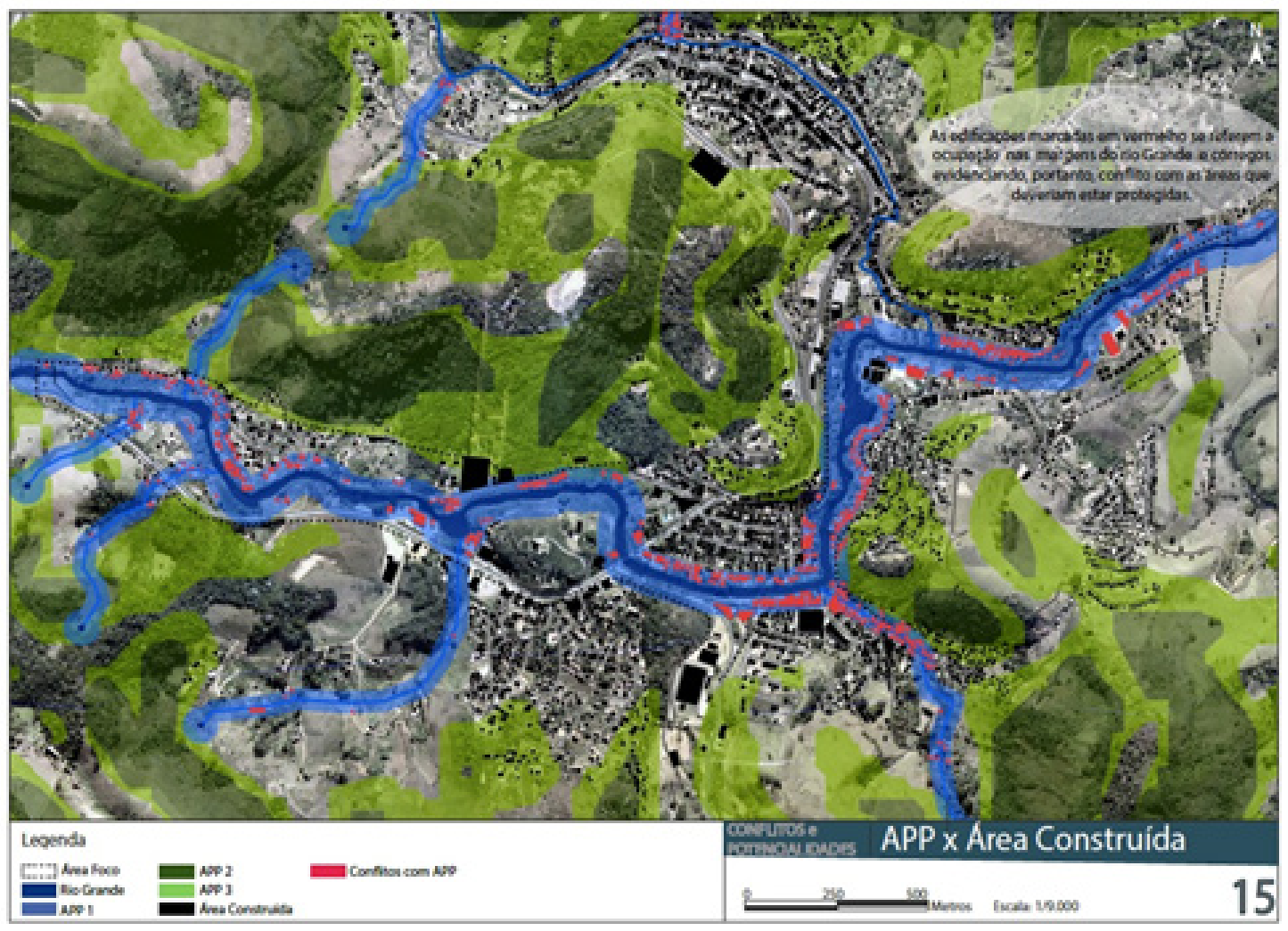

Figura 10 - Mapa indicativo das APPs e Uso e Ocupação:

Edição própria em ArcGis, 2017

te com outros sistemas de mitigação de enchentes e drenagem. Promove a melhoria da qualidade da água e pode servir para fins recreativos.

Bacia de Infiltração: além de reter o fluxo excedente da água, tem capacidade de infiltrá-la no solo, sendo que seu uso está condicionado à análise de permeabilidade do solo.

Biovaletas: Em menor escala pode ser implantada em passeios e vias, boa solução para aumentar a permeabilidade do solo e não sobrecarregar o sistema de drenagem.

Retenção da erosão das margens dos rios com sistemas naturas de plantio e contenções permeáveis por meio de técnicas de bioengenharia.
Arborização: tem diversas funções, dentre as quais: auxilia no processo de infiltração da água no solo, promove a melhoria do microclima local e humaniza os espaços urbanos.

Eco depuração: sistema de tratamento de águas residuais, esgoto e águas pluviais por meio de plantas macrofilas. Baixo custo, inferior às técnicas tradicionais de tratamento químico.

Ressalta-se que foram descritas algumas das opções possíveis a ser implantadas. Um bom desempenho da infraestrutura verde depende da combinação de diversos sistemas que, quando integrados, podem ser implantados em menores proporções e em diferentes partes da cidade, além de oferecer menos riscos associados à falha ou sobrecarga de algum dos sistemas. 
Enfatiza-se que a aplicação de técnicas de infraestrutura verde e aspectos legislativos devem ser associados à efetiva fiscalização das áreas protegidas e ao comprometimento cidadão, na promoção da requalificação dos espaços urbanos e na diminuição dos riscos.

\section{Circulação e mobilidade}

A política de mobilidade se baseia no Desenvolvimento Orientado pelo Transporte (DOT), que projeta o transporte público como fator de desenvolvimento, priorizando o pedestre e o incentivo à utilização do transporte público. Fundamenta-se na ideia de cidade compacta (Rogers, 2001) como forma de otimizar os deslocamentos poupando tempo e energia, promover o adensamento e utilizar o transporte público para conectar as zonas distantes, prevendo que seja eficiente e de qualidade, oferecendo ao usuário opções de mobilidade. Deve-se priorizar usos mistos para que o ambiente urbano se torne mais atrativo, reforçando centralidades e núcleos de bairros e encurtando as distâncias. O uso da bicicleta deve ser estimulado com ciclovias e os deslocamentos a pé potencializados. Propõe-se a criação de rotas de ciclovias e ciclofaixas para favorecer a mobilidade intrabairro, bem como para conectar os bairros, em deslocamentos de pequenas distâncias. Essas mudanças devem estar aliadas a uma política de redução do uso do veículo particular com baixa capacidade de carga.

A aplicação desses conceitos no plano urbano se reflete, primeiramente, na proposta de reestruturação do sistema viário e modais existentes. A análise do relevo e das conexões desejadas geraram quatro cenários para as seções de vias de circulação. Para vencer grandes desníveis ou as acentuadas inclinações, a circulação se faz por meio de rampas e escadas, adaptadas para o usuário conduzir a pé o veículo não-motorizado. Além das rotas cicloviárias, é necessária a instalação de: equipamentos de apoio, bicicletários, opções de aluguel de bicicletas, locais para manutenção e conexões com outras modalidades de transporte, para que o uso da bicicleta seja viabilizado e faça parte de uma rede de transporte.
A acessibilidade é um ponto chave ao se pensar na mobilidade. A proposta da reestruturação viária prevê o alargamento da faixa útil das calçadas, sinalização horizontal com piso táctil e vertical para evitar conflitos de uso com ciclistas e outros transportes, elevação das faixas de travessia para controlar a velocidade dos veículos motorizados ou construção de rampas acessíveis e de novas travessias sobre o Rio Grande. O parque linear, previsto nas margens alagáveis, funciona como um grande elemento integrador, que confere unidade ao tecido urbano.

Com relação ao transporte público, pretende-se manter o sistema de transporte coletivo rodoviário, mais viável economicamente, sendo estudada a possibilidade de implementação de um sistema de Veículo Leve sobre Trilhos (VLT), que incorpore alguns conceitos como a faixa exclusiva, corredores de acesso, embarque em nível acessível e rotas mais rápidas e integradas a outros modais. Para implantação desse sistema, deverá ocorrer em alguma zonas um projeto de realinhamento, capaz de suportar o fluxo do tráfego previsto pelo adensamento no entorno imediato aos eixos. Espera-se alcançar com essas medidas a universalização de acesso ao transporte público e mobilidade inclusiva. (Fig. 11)

\section{Potencialidades de Uso e OCupação do Solo}

O objetivo maior deste trabalho se delineia por meio das políticas e diretrizes adotadas para o meio ambiente, infraestrutura, transportes e mobilidade urbana. Busca-se complementar a proposição de diretrizes de ocupação, do uso do solo e as orientações urbanísticas que fornecerão subsídio para a formulação de outras políticas urbanas. Uma das maiores preocupações da pesquisa diz respeito à ocupação das margens do Rio Grande, aos riscos ambientais associados e a forma de condução do processo de liberação da ocupação humana das APPs. Assim, a política adotada considera a classe de risco do imóvel quanto a enchentes e enxurradas e a compatibilidade do uso nas áreas de conflito com as APPS, a cota altimétrica de implantação, o afastamento das margens dos rios e córregos, a porcentagem total da área do 


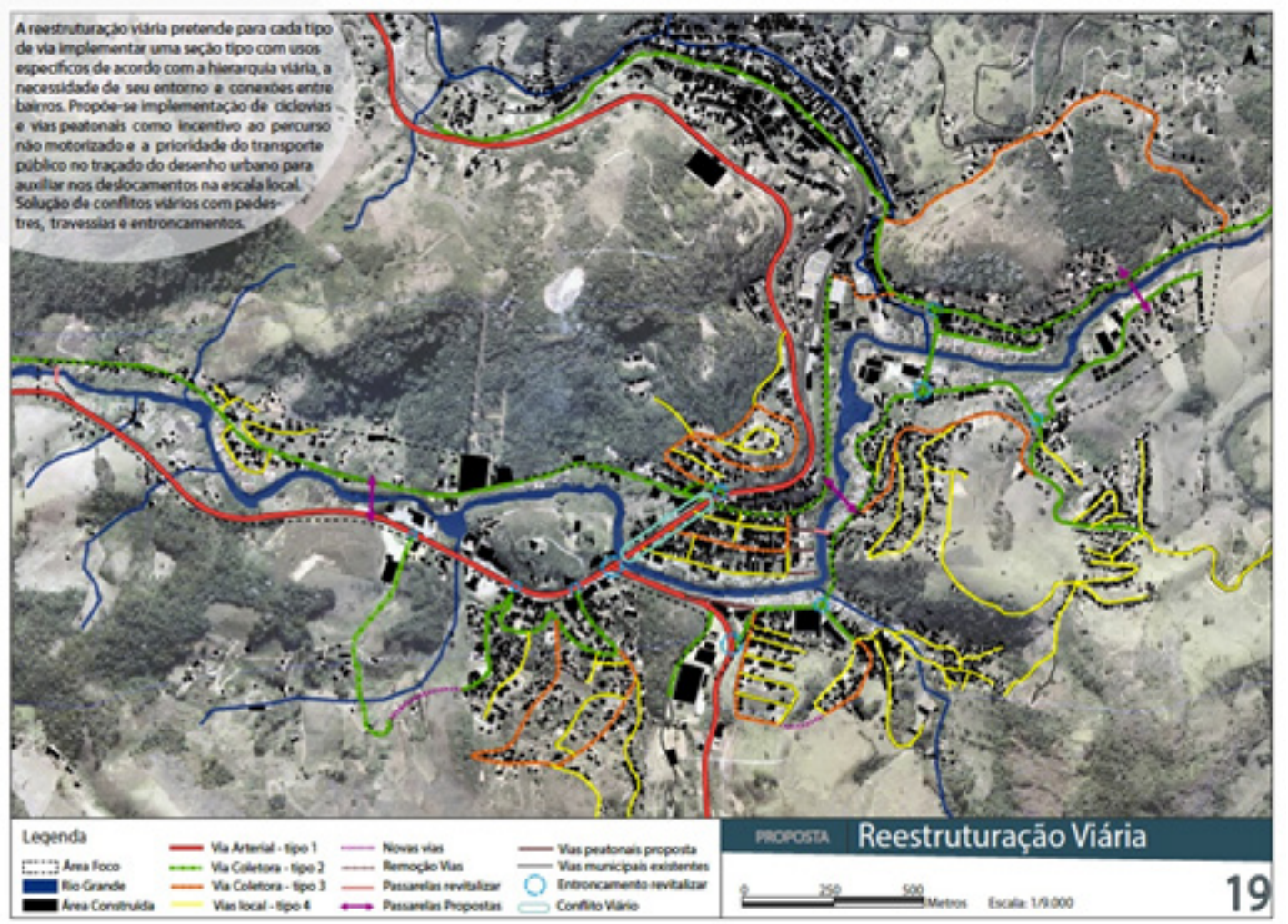

Figura 11 - Mapa de reestruturação viária proposta.

Fonte: Edição própria em ArcGis, 2017

imóvel inserida na área de preservação, se o imóvel é próprio ou alugado, além de aspectos de interesse público, e se o imóvel tem caráter histórico ou cultural.

Em áreas de Uso Não Permitido prevê-se a demolição de edificações, sob risco e inadequadas à habitação, e a implementação de usos temporários, ligados aos esportes e lazer, sendo providenciado reassentamento das famílias residentes ou das atividades de acordo com o uso (Fig. 12). As premissas de realocação são:

O reassentamento de grupos de edificações uni ou multifamiliares deve privilegiar áreas próximas a sua origem, sem oferecer riscos; se compulsório, deve ter aceitação do proprietário, visando a melhoria de habitabilidade e segurança; permite-se outras opções de realocação: indenização, compra assistida e auxílio financeiro para quitação de imóvel.
Edificações comerciais, de serviços e de uso misto, devem contemplar todas as diretrizes permitidas para as habitações, podendo os imóveis com área construída de até $35 \mathrm{~m}^{2}$ ter seu valor acrescido em $50 \%$ para a modalidade de compra assistida. Esse benefício é válido em casos de ser fonte de renda familiar e único imóvel da família ou comercial.

Imóveis alugados devem prever indenização mediante vistoria pelas benfeitorias realizadas e auxílio financeiro ao proprietário. Os valores devem seguir tabela por tipo de materiais empregados. A indenização pode ser acrescida em $50 \%$ perante comprovação de renda familiar e, caso seja única fonte de renda para a modalidade de compra assistida.

Nas Permissões de uso condicionado, será expedida uma licença de uso mediante ao cumprimento de alguns critérios, a saber: 


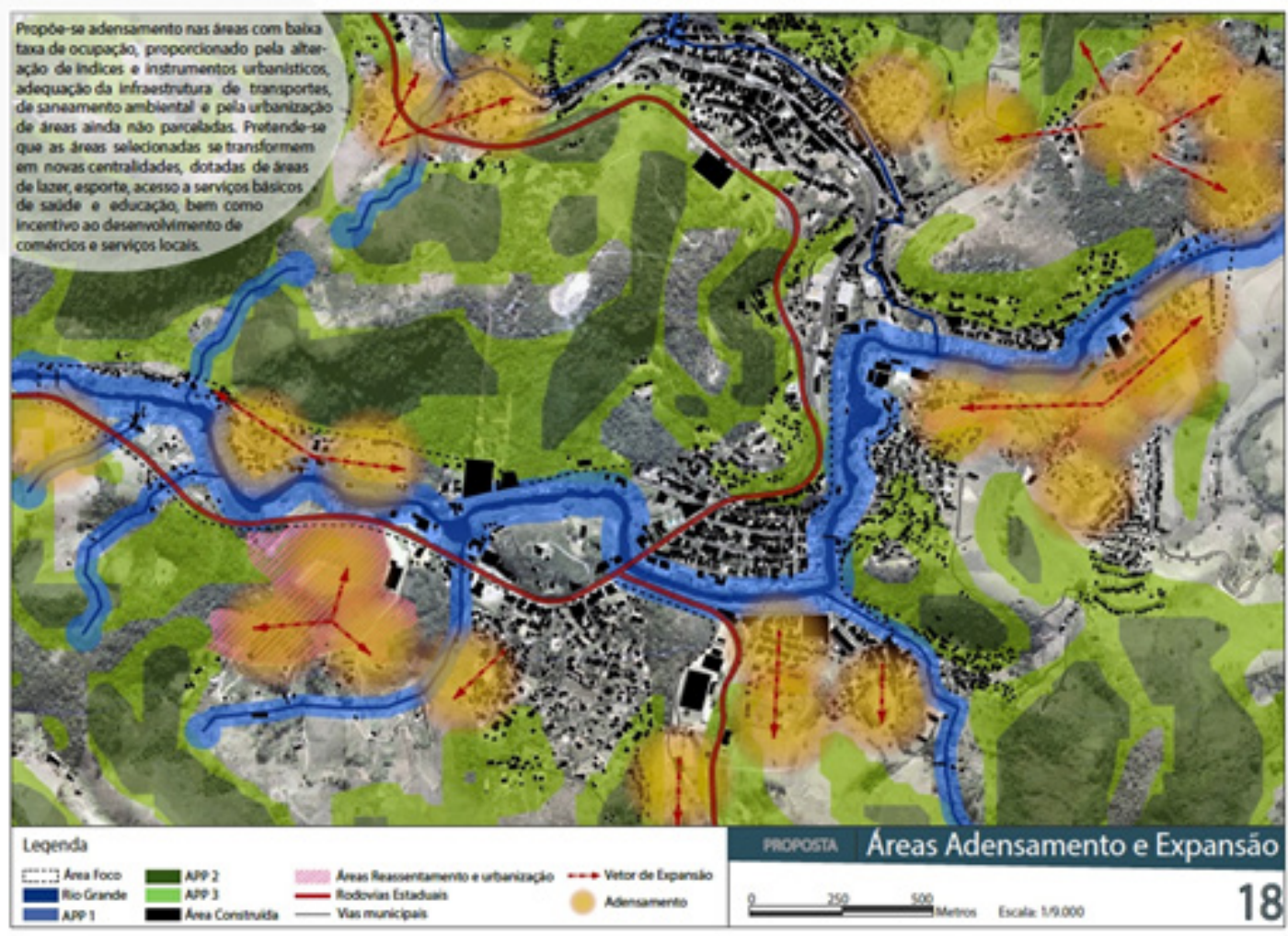

Figura 12 - Mapa uso do solo proposto.

Fonte: Edição própria em ArcGis, 2017

Não são permitidos, nem aprovados em órgão competente qualquer solicitação de ampliação nas áreas de preservação, exceto em casos de utilidade ou interesse público.

É permitida a permanência de edifícios históricos ou culturais, desde que sem alto risco.

Em caso de venda do imóvel, deverá ser assinado pelo novo proprietário declaração de ciência das restrições de uso.

Ficam os proprietários desses imóveis livres para negociar com órgãos públicos, por espontânea vontade, alternativas de venda dos mesmos.

Além desses casos, imóveis localizados a $15 \mathrm{~m}$ a partir da borda das APPs, são passíveis de negociação com órgão público responsável pela desapropriação, mediante acordo e contrapartida com município, Estado, União ou parcerias privadas. São identificadas novas áreas a urbanizar, seguindo a premissa de cidades compactas (Rogers, 2001), com aproveitamento da estrutura viária, em áreas valorizadas, próximas a novas centralidades e abastecida de serviços e infraestrutura, sob as premissas de: implementação de quadras abertas, com comércio e serviços, equipamentos públicos e cotas de habitação de interesse social. Além das áreas a serem urbanizadas, são identificadas áreas de adensamento e vetores de expansão urbana, respeitando as condicionantes ambientais e de ocupação do solo.

\section{Considerações Finais}

Este artigo intencionou apresentar os resultados da aplicação da ferramenta do Sistema de Informações Geográficas na análise 
da Sub-bacia Hidrográfica do Rio Grande, localizado em Bom Jardim, na região Serrana do Rio de Janeiro, assolado em 2011 pela tragédia das chuvas que afetaram toda a região, com perdas humanas e patrimoniais significativas. As causas principais identificadas relativas aos impactos urbanos foram os processos de antropização e de ocupação irregular nas margens do Rio Grande, gerando os maiores prejuízos materiais. Nesse sentido, a falta de planejamento, a precária urbanização e a ordenação urbana deficientes no município de pequeno porte, indicam que eventos dessa natureza podem voltar a ocorrer, tornando ainda mais urgente a necessidade de buscarmos formas de atuação, de modo a contribuir para reverter esse quadro a partir da elaboração de um Plano de Estruturação Urbana (PEU), considerando a ocupação às margens do Rio Grande.

O estudo foi realizado em diversas escalas de análise, considerando desde a inserção na Bacia Hidrográfica na escala macro, a análise tipo-morfológica no município de Bom Jardim e a área foco, considerando o recorte urbano ao longo do Rio Grande, em Bom Jardim. Foram analisados aspectos legislativos, com o entendimento do Plano Diretor e do código de posturas municipal, e ambientais, com o Código Florestal, no sentido de um maior entendimento sobre a sua aplicação e as suas interrelações e sobreposições legais no sentido do uso e ocupação do solo.

Foram identificadas as Unidades de Paisagem, também desde a escala meso à local, que direcionaram o aprofundamento do estudo para o recorte urbano e as proposições e diretrizes previstas para o PEU. Os dados demográficos e socioeconômicos da região e do município, indicaram as demandas e as principais carências locais. A análise cartográfica foi fundamental para a identificação de potencialidades e fragilidades e na construção de cenários prospectivos, realizada com a sobreposição dos mapas e a leitura multitemática dos mesmos.

Um dos principais resultados do estudo indica a implantação de um parque linear ao longo do percurso do Rio Grande e seus afluentes, em função de benefícios ambientais, dentre os quais, destacam-se: da área permeável e diminuição de ocorrência e impactos das enchentes; da garantia de acesso do uso dos espa- ços livres públicos; das novas opções de lazer, esporte e cultura; do local para implementação de sistemas de infraestrutura verde; e da melhoria na qualidade da água. As análises realizadas fazem uma leitura do suporte geobiofísico, que proporcionam utilização dos recursos de forma sustentável, restabelecimento das funções ecológicas e conexões com outras áreas preservadas, e conhecimento das áreas passíveis de ocupação, preservação ou recuperação. Essas informações auxiliam no desenvolvimento de políticas de ordenamento territorial, de requalificação da paisagem e de ecossistemas naturais, bem como, na diminuição de riscos ambientais.

\section{RefERÊNCIAS BibliográficAS}

AGEVAP (s/d) Plano de Recursos Hídricos da Bacia do Rio Paraíba do Sul - Caderno de Ações Área de Atuação BNG2. Resende: COPPETEC. Disponível em http://www.ceivap.org.br/downloads/cadernos/BNG2.pdf. Acesso: 01 out. 2019.

BANCO MUNDIAL. Avaliação de Perdas e Danos: Inundações e deslizamentos na Região Serrana do Rio e Janeiro- Janeiro de 2011. Brasília: Banco Mundial, 2012.

BRASIL. Plano Diretor Participativo: guia para elaboração para os municípios e cidadãos. Ministério das Cidades (MCID), 2004. Disponível em https://bibliotecadigital.seplan.planejamento.gov.br/handle/iditem/181. Acesso: 01 out. 2019.

CALDERANO FILHO, B. et al. Caracterização dos solos do Médio Alto Curso do Rio Grande (RJ): Subsídios ao Planejamento de Paisagens Rurais Montanhosas da Serra do Mar. Anais Congresso Brasileiro de Ciência do Solo 34. Viçosa, MG: SBS, 2013.

LAMAS, J.M.R.G. Morfologia urbana e desenho da cidade. sl: Fundação Calouste Gulbenkian, 1993.

LYNCH, K. A theory of Good city form. Cambridge: The MIT Press, 1981

MAGNOLI, M. Em busca de outros espaços livres de edificação. Revista Paisagem e Ambiente - Ensaios, n² 21. São Paulo: FAUUSP, 2006, p. 143-173.

MARICATO, E. e JUNIOR, O. (2007) Construindo a política urbana: participação democrática e o direito à cidade. In: RIBEIRO, L. e SANTOS, O. (org.). As metrópoles e a questão social brasileira. Rio de Janeiro: Editora Revan; Fase (v. 1, pp. 165-195)

PNUD. Atlas do Desenvolvimento Humano do Brasil. 2013. Disponível em http://www.atlasbrasil.org.br/2013/pt/. Acesso em: 01 out. 2019.

RHEINGANTZ, P.A. et al. Observando a qualidade do lugar: Procedimentos de Avaliação Pós-Ocupação. Rio de Janeiro: PROARQ-FAU-UFRJ. Disponível em https://www.researchgate. net/publication/308740248_Observando_a_Qualidade_do_Lugar_procedimentos_para_a_avaliacao_pos-ocupacao. Acesso: 01 out. 2019

ROGERS, R. Cities for a small planet. London: Faber and Faber Limited, 2001.

SAMPAIO, M.A. et al. Análise Tipo-Morfológica da Paisagem e do Sistema de Espaços Livres de Edificação da Cidade do Rio de Janeiro. In: Tângari et al. (orgs). Sistema de espaços livres 
- o cotidiano, apropriações e ausências. Rio de Janeiro: FAU/UFRJ-PROARQ, v.1., 2009. pp. 206-225.

SANTIN, J. e MARANGONO, E. Estatuto da Cidade e os instrumentos de política urbana para proteção do patrimônio histórico: outorga onerosa e transferência do direito de construir. História, v.27, n.2, p.89-109), 2008. Disponível em: http://www.scielo.br/scielo.php?pi$\mathrm{d}=$ S0101-90742008000200006\&script=sci_abstract\&tIng=pt. Acesso: 01 out. 2019.

Santos. M.O.G. O Planeamento por Cenários como Resposta das Organizações a Desafios Colocados na Época Actual. Unversidade de Évora, 2013. Disponível em: http://home.uevora. $\mathrm{pt} / \sim \mathrm{mos} a n t o s / d o w n l o a d / P l a n e a m e n t o p o r C e n a r i o s \_01 J u n 13 . p d f$. Acesso: 01 out. 2019.

SEC Notas para um diagnóstico preliminar: A Cultura na Região Serrana. Plano Estadual de Cultura - Secretaria Estadual de Cultura, 2010.

TÂNGARI, V., SCHLEE M., ANDRADE, R. (Org.). Sistema de espaços livres - o cotidiano, apropriações e ausências. Rio de Janeiro: FAU/UFRJ-PROARQ, v.1., 2009. p.496

VILLAÇA, F. (1998) Espaço intra-urbano no Brasil. São Paulo, Nobel, 2009.

Agradecimentos

O presente trabalho foi realizado com apoio da Coordenação de Aperfeiçoamento de Pessoal de Nível Superior - Brasil (CAPES) - Código de Financiamento 001, e da FAPERJ, com auxílio APQ-1 e bolsa de iniciação científica.

\section{AgRADECIMENTOS}

O presente trabalho foi realizado com apoio da Coordenação de Aperfeiçoamento de Pessoal de Nível Superior - Brasil (CAPES) Código de Financiamento 001, e da FAPERJ, com auxílio APQ-1, bolsa JCNE e bolsa de iniciação científica.

\section{Ludmila Pacheco Erthal}

Universidade Federal Rural do Rio de Janeiro, Departamento

de Arquitetura e Urbanismo, Programa de Pós-Graduação em

Desenvolvimento Territorial e Políticas Públicas

BR 465, Km 7, CEP 23890-000, Seropédica - RJ

https://orcid.org/0000-0003-4661-6954

ludperthal@gmail.com

\section{Denise de Alcantara Pereira}

Universidade Federal Rural do Rio de Janeiro, Departamento

de Arquitetura e Urbanismo, Programa de Pós-Graduação em

Desenvolvimento Territorial e Políticas Públicas

BR 465, Km 7, CEP 23890-000, Seropédica - RJ

https://orcid.org/0000-0002-6482-0943

denisedealcantara@gmail.com

Notas do Editor:

Data de submissão: 08/10/2019

Aceite: $22 / 08 / 2020$

Revisão: RMO 